
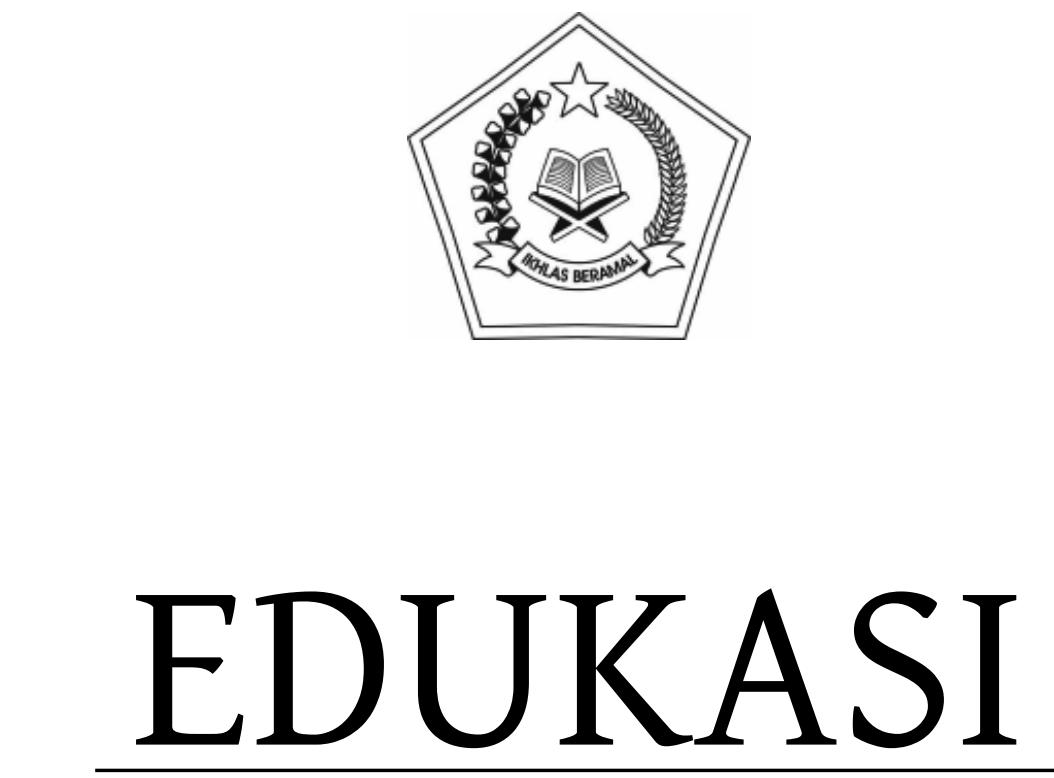

JURNAL PENELITIAN PENDIDIKAN AGAMA DAN KEAGAMAAN

VOLUME 13, NOMOR 3, DESEMBER 2015 


\title{
SISTIM PENDIDIKAN DAN PENGKAJIAN ISLAM DI PESANTREN DALAM KONTEK DINAMIKA STUDI ISLAM INTERNASIONAL
}

\author{
EDUCATIONAL SYSTEM AND ISLAMIC STUDIES \\ AT PESANTREN IN THE CONTEXT OF DYNAMIC \\ ON INTERNATIONAL ISLAMIC STUDIES
}

\author{
Hamid Fahmy Zarkasyi \\ Universitas Darussalam Gontor Ponorogo \\ Jl. Raya Siman Km. 6, Siman, Kec. Ponorogo, Jawa Timur 63471 \\ Email: hfzark@yahoo.co.uk
}

Naskah diterima 3 Oktober 2015, direvisi 2 Nopember 2015, disetujui 8 Desember 2015

\begin{abstract}
Pesantren is an educational institution that specializes in Tafaqquh fi al-Din. Hence, the educational system of the pesantren becomes knowledge source of Islam and as a place for developing moral of student. Role of the pesantren is relevant to a discourse on quality development for Human Resources of Islam followers that is designed integrative between intellectual and moral. An integration of the intellectuality and morality constitutes an educational strength at the pesantren. Such strength makes the pesantren already contribute in the home country. Hence, if the pesantren will be "sold" to international world, it is necessary to consider aspect of the strengths. This writing tries giving an opinion on developing the pesantren in general context so that it can contribute to the Islamic studies at the international world.
\end{abstract}

Keywords :Educational system, pesantren, Islamic studies, International
Abstrak

Pesantren adalah lembaga pendidikan yang mengkhususkan dirinya untuk Tafaqquh fi al-Din. Karena itu sistem pendidikan pesantren menjadi sumber pengetahuan agama Islam dan tempat pembinaan moral anak didik. Peran pesantren tersebut relevan dengan wacana pengembangan kualitas SDM umat Islam yang integratif antara intelektual dan moral. Integrasi intelektualitas dan moralitas merupakan kekuatan pendidikan di pesantren. Kekuatan inilah yang membuat pesantren telah berkontribusi dalam pentas nasional. Oleh sebab itujika pesantren akan "dijual" ke dunia internasional perlu dipertimbangkan aspek kekuatan-kekuatan tersebut. Tulisan ini mencoba memberi sumbangan pemikiran kearah pengembangan pesantren secara umum agar dapat memberi sumbangsih pada studi Islam di dunia internasional.

Kata Kunci : Sistem pendidikan, pesantren, studi Islam, Internasional 


\section{PENDAHULUAN}

Pesantren secara umum adalah lembaga pendidikan yang mengkhususkan dirinya untuk Tafaqquh fi al-Din, namun yang unik pada pesantren adalah sistim pendidikannya yang menjadi sumber pengetahuan agama Islam dan tempat pembianaan moral anak didik. Peran pesantren menjadi semakin relevan jika dikaitkan dengan wacana pengembangan kualitas SDM umat Islam yang saat ini sedang mencari sistim yang mampu mengintegrasikan pengembangan intelektual dan moral secara simultan. Namun, peran yang dimainkan pesantren tidak seimbang dengan besarnya tantangan yang dihadapi umat Islam yang begitu kompleks dan massif. Pesantren sendiri di Indonesia masih terletak dipinggiran sistim pendidikan nasional atau mungkin diluarnya, sehingga SDM yang dihasilkan oleh pesantren ini tidak dapat berperan maksimal di pentas nasional. Banyak faktor baik internal maupun eksternal yang membawa pesantren pada kondisi seperti ini. Oleh sebab itu jika pesantren akan di "jual" ke dunia internasional perlu mempertimbangkan berbagai aspeknya. Tulisan ini mencoba memberi sumbangan pemikiran kearah pengembangan pesantren secara umum agar dapat memberi sumbangsih pada studi Islam di dunia internasional.

\section{Makna Pesantren}

Untuk memberi sumbangan pemikiran tentang pesantren, diperlukan pengertian pesantren yang benar dan komprehensif. Sebab pesantren bukanlah lembaga pendidikan biasa dan tidak bisa dibandingkan dengan lembaga pendidikan di negara-negara lain. Kesalahan dalam memahami obyek kajian akan berakibat pada kesalahan akan pemikiran yang akan disumbangkan. Diantara para pengamat mendefinisikan pesantren dengan sangat sederhana dan tidak menggambarkan keseluruhan aspeknya. Abdurrahman Wahid, misalnya mendefinisikan pesantren secara teknis sebagai tempat di mana santri tinggal. ${ }^{1}$ Sedangkan Mahmud Yunus, mendefinisikannya sebagai tempat santri belajar agama Islam. ${ }^{2}$ Abdurrahman Mas'ud, mendefinisikan pesantren sebagai tempat di mana para santri mencurahkan sebagian besar waktunya untuk hidup dan dan mencari ilmu pengetahuan. (refers to a place where the santri devotes most of hisor her time to live in and acquire knowledge). ${ }^{3}$ Definisi yang lebih lengkap disampaikan oleh Menurut Zamakhsyari Dhofir yang mengartikan pesantren sebagai lembaga pendidikan Islam yang memiliki pondok, masjid, santri, dan pengajaran kitab kuning dan kyai. ${ }^{4}$ Disini elemen pondok pesantren lebih lengkap, namun penekanannya pada terletak pada kitab kuning.

Pengertian lebih lengkap lagi terdapat dalam Kamus Besar Bahasa Indonesia yang mendefinisikannya sebagai lembaga pendidikan Islam dimana para santri biasa tinggal di pondok (asrama) dengan materi pengajaran kitab-kitab klasik dan kitab kitab umum bertujuan untuk menguasai ilmu agama Islam secara detail serta mengamalkan sebagai pedoman hidup keseharian dengan menekankan penting moral dalam kehidupan bermasyarakat. $^{5}$

1 Abdurrahman Wahid, 2001. Menggerakkan Tradisi, Esai-esai Pesantren, Yogyakarta: LKIS, h. 17

${ }^{2}$ Mahmud Yunus, 1990. Sejarah Pendidikan Islam di Indonesia, Jakarta: Hidakarya, h. 231

${ }^{3}$ Ismail SM (ed), 2000. Pendidikan Islam, Demokrasi dan Masyarakat Madani, Yogyakarta : Pustaka Pelajar, Cet ke-1, h.17

${ }^{4}$ Zamakhsyari Dhoefier, 1984. Tradisi Pesantren, studi Tentang Pandangan Hidup Kyai, Jakarta: LP3ES, h. 18

${ }^{5}$ Abu Hamid, "Sistem Pendidikan Madrasah dan Pesantren di Sulawesi Selatan", dalam Taufik Abdullah (ed), Agama dan Perubahan Sosial, 1983. Jakarta: Rajawali Press, h. 329 
Definisi ini menekankan pada sistim asrama dan materi pengajaran pada kitab-kitab klasik dan pengamalannya dalam kehidupan sosial. Sementara M. Arifin menambah elemen kyai sebagai pemegang otoritasnya dan mendefinisikannya sebagai berikut: "Suatu lembaga pendidikan agama Islam yang tumbuh serta diakui masyarakat sekitar, dengan sistem asrama (komplek) di mana santri santri menerima pendidikan agama melalui sistem pengajian atau madrasah yang sepenuhnya berada di bawah kedaulatan dari leadership seorang atau beberapa orang kyai dengan ciri-ciri khas yang bersifat karismatik serta independen dalam segala hal". ${ }^{6}$

Definisi yang lebih lengkap dengan menyempurnakan elemen-elemennya datang dari KH. Imam Zarkasyi dan arti pesantren menjadi:

....sebagai lembaga pendidikan Islam dengan sistem asrama atau pondok, di mana kyai sebagai figur sentralnya, mesjid sebagai pusat kegiatan yang menjiwainya, dan pengajaran agama Islam dibawah bimbingan kyai yang diikuti santri sebagai kegiatan utamanya. $^{7}$

Dari pengertian-pengertian diatas maka sebuah lembaga pendidikan dapat dinamakan pesantren jika memiliki standar elemen yang telah disepakati dalam definisi diatas yang dapat disarikan menjadi lima elemen yaitu 1) asrama atau pondok 2) Kyai 3) Masjid 4) Pengajaran agama Islam baik dengan kitab klasik maupun kitab umum dan 5) santri yang belajar di dalamnya. Jika pesantren tidak memenuhi kelima elemen diatas dapat dikatakan sebagai

${ }^{6}$ M. Arifin, Kapita Selekta Pendidikan (Islam dan Umum), 1991. Jakarta: Bumi Aksara, h. 240

7 Amir Hamzah Wirosukarto,et.al., 1996. KH. Imam Zarkasyi dari Gontor Merintis Pesantren Modern Ponorogo: Gontor Press, h.5 bukan lembaga pendidikan yang disebut pesantren. Sebuah sekolah yang berasrama misalnya tidak dapat menyebut dirinya pesantren, jika tidak memiliki Kyai sebagai figure sentralnya dan pengajaran agama sebagai kegiatan utamanya.

\section{Model-Model Pengajaran}

Definisi pesantren diatas lebih merujuk kepada aspek atau elemen pesantren. Namun dari pengembangan aspek pengajaran pesantren-pesantren itu memiliki perkembangan yang berbeda antara satu dengan yang lainnya. Diantara pesantren ada yang berkembang seiring dengan perkembangan zaman atau perkembangan sistim pendidikan, baik tingkat nasional maupun internasional. Namun ada pula pesantren yang tetap konsisten dengan sistim lama, meskipun tetap mengembangkan beberapa aspeknya. Dari perkembangan ini maka pesantren dapat dikelompokkan menjadi dua kelompok besar, yaitu: pesantren salafi yang tetap mempertahankan kitab-kitab Islam klasik sebagai inti pendidikan di pesantren dan pesantren modern yang telah memasukkan pelajaran-pelajaran umum dalam madrasahmadarasah yang dikembangkannya, atau membuka tipe sekolah-sekolah umum dalam lingkungan pesantren. Dari dua kategori utama ini kita masih dapat memerincikan lagi menjadi beberapa model yang berbeda, yang sekurang-kurangnya terdapat lima model.

Model Pertama. Pesantren model ini terikat dengan sistim pesantren lama yang seringkali disebut pesantren salafiyyah. Ciri-ciri pesantren salafiyyah adalah sbb 1) Kegiatan utama adalah pangkajian kitab-kitab klasik semata-mata. 2) Metode yang digunakan adalah tradisional seperti sorogan, wetonan, dan hafalan. 3) tidak menggunakan sistem klasikal, atau kelas yang terstruktur dengan masa belajar 
tertentu. Prestasi belajar dan pencapaian pengetahuan seorang santri diukur dari sejumlah kitab-kitab yang telah pernah dipelajarinya dan kepada ulama mana ia berguru. 4) Tujuan pendidikannya adalah untuk meningkatkan akhlaq mulia dalam bersikap dan bertingkah laku serta menyiapkan para santri mengamalkan ilmu dan akhlaq itu dalam kehidupan sehari-hari di masyarakat.

Model Kedua. Pesantren ini seperti model pertama yaitu tetap mempertahankan penggunaan kitab-kitab klasik. Hanya saja kitab-kitab itu diajarkan dalam bentuk klasikal dan non klasikal. Selain itu sebagai tambahan diajarkan pula pelajaran ekstrakurikuler seperti keterampilan dan praktek keorganisasian.

Model Ketiga. Pesantren yang masih mempertahankan sistim salafiyyah dengan pengkajian kitab-kitab klassiknya, namun membuka sistim pendidikan formal berbentuk madrasah, sekolah dan bahkan perguruan tinggi. Pengkajian kitab klassik merupaan materi yang wajib diikuti oleh seluruh santri yang mengikuti pelajaran di madrasah, sekolah, dan perguruan tinggi, meskipun masih terdapat santri yang secara khusus mengikuti pengajian kitab-kitab klasik saja. Di pesantren ini terdapat majelis taklim dan pendidikan keterampilan.

Model Keempat. Pesantren yang mengutamakan pengajaran ilmu-ilmu keterampilan di samping ilmu-ilmu agama sebagai mata pelajaran pokok. Pesantren ini mendidik para santrinya untuk memahami dan dapat melaksanakan berbagai keterampilan guna dijadikan bekal hidupnya. Dengan demikian kegiatan pendidikannya meliputi kegiatan kelas, praktik di laboratorium, bengkel, kebun/ lapangan.

Model Kelima. Pesantren model ini telah dikembangkan sejalan dengan perkembangan sistim pendidikan nasional maupun internasional. Oleh sebab itu dapat digambarkan sbb: 1) Kegiatan utama adalah pengajaran ilmu pengetahuan agama dan umum sekaligus. 2) Metode yang digunakan adalah modern yaitu menggunakan sistem klasikal, atau kelas yang terstruktur dengan masa belajar tertentu, sehingga 4 pelajaran itu dapat ditempuh dalam waktu tertentu secara terukur. 3) Materi pelajaran agama tetap merujuk kepada kitab-kitab klasik, namaun dalam bentuk ringkasan yang disusun secara madras; sedangkan materi pelajaran umum (sains) mengikuti standar pelajaran pada sekolah-sekolah modern. 4) Sistim pendidikannya diatur sebagaimana lazimnya sebuah sekolah dimana prestasi belajar dan pencapaian pengetahuan seorang santri diukur dari ujian-ujian yang diadakan pada setiap semester. 5) Meskipun pengajarannya menggunakan sistim sekolah namun sistim utama pendidikannya adalah pesantren yang diwarnai oleh suasana dan jiwa-jiwa pesantren dimana Kyai menjadi figure sentralnya dan masjid sebagai pusat kegiatan yang menjiwainya. Selain menekankan pada pengajaran ilmu pengetahuan agama dan umum pesantren model ini menyediakan berbagai kegiatan ekstra berupa organisasi, kemasyarakatan, keterampilan, kesenian, kepramukaan dan sebagainya.

\section{Model-Model Pendidikan}

Model-model yang telah disebutkan diatas sekedar untuk menunjukkan potensipotensi yang dimiliki sistim pendidikan pesantren dari aspek pengajaran dan pendidikan di dalam lingkungan pesantren. Namun, potensi pesantren sebagai lembaga yang memiliki model lingkungan dan suasana yang mendidik tidak kalah pentingnya dibanding dengan potensi pengajaran seperti yang disebutkan diatas. Maka berikut ini model-model pendidikan 
informal dan non-formal yang merupakan kelebihan dan ciri khas pesantren.

\section{Pendidikan Keteladanan}

Pendidikan keteladan di pesantren adalah suatu menyatu dengan sistim, sebab lembaga ini telah sejak awal dipimpin oleh Kyai yang layak menjadi teladan para santri dan bahkan masyarakat. Dari kesalehan Kyai yang nampak dalam pengamalan ibadah ritual hingga perilakunya dalam kehidupan sehari-hari seperti keikhlasan dalam mengajar para santri, kesederhanaan dan kemandiriannya, ketawadhuannya dalam pergaulan di masyarakat telah menjadi contoh yang positif.

\section{Pendidikan Pembiasaan}

Islam merupakan agama yang menjalin kebersamaan dalam kehidupan social dan karena itu di dalamnya terdapat ibadah ritual dan ibadah amaliyah yang memerlukan kebersamaan. Untuk menjalin kebersamaan ini diperlukan suatu pembiasaanpembiasaan. Lingkungan pesantren dalam hal ini merupakan tempat yang sangat kondusif untuk mendidikan santri dengan pembiasaan-pembiasaan. Bahkan kebiasan untuk bersopan santun, bersikap jujur dalam segala kegiatan, amanah dalam mengerjakan sesuatu tugas, shalat berjamaah, sopan pada kyai dan ustadz dan sebagainya sangat mudah untuk dilaksanakan dilingkungan pesantren. Latihan dan pembiasaan sejalan dengan apa yang dinyatakan oleh al-Ghazali bahwa: Sesungguhnya perilaku manusia menjadi kuat dengan seringnnya dilakukan perbuatan yang sesuai dengannya, disertai ketaatan dan keyakinan bahwa apa yang dilakukannya adalah baik dan diridhai". ${ }^{8}$

${ }^{8}$ Al-Ghazali, 1977. Ihya Ulumuddin, Jilid III, Daral-Mishri: Beirut, h. 615

\section{Pendidikan Ibrah}

Ibrah berarti renungan dan pemikiran. Pendidikan ibrah maksudnya adalah mengambil pelajaran dari suatu peristiwa. Ibrah adalah suatu kondisi psikis yang membawa manusia mengetahui inti dari suatu peristiwa yang disaksikan, diperhatikan, disimpulkan, ditimbangtimbang, diukur dan diputuskan secara rasional, sehingga kesimpulannya dapat mempengaruhi hati untuk tunduk kepadanya, lalu mendorongnya kepada perilaku yang sesuai. ${ }^{9}$ Pendidikan seperti ini dapat mudah dilakukan oleh figur Kyai yang kaya dengan kisah-kisah teladan dalam sejarah Islam, fenomena alam atau peristiwa-peristiwa yang terjadi, baik di masa lalu maupun sekarang yang dengan keluasan ilmu Kyai dapat ditafsirkan sehingga menjadi ibrah bagi para santrinya.

\section{Pendidikan Mauidzah}

Mauidzah menurut Rasyid Ridla adalah:"nasehat peringatan atas kebaikan dan kebenaran dengan jalan apa yang dapat menyentuh hati dan membangkitkannya untuk mengamalkan". ${ }^{10}$ Apa yang dimiliki pesantren adalah suasana dimana Kyai dan para ustadh dapat dengan mudah memberikan mauidzah kepada para santri dalam berbagai hal baik ibadah mahdhah maupun ibadah muamalah dalam bentuk motivasi, peringatan tentang dosa dan pahala dan sebagainya.

\section{Pendidikan Kedisiplinan}

Disiplin maksudnya adalah untuk menjaga konsistensi atau sikap istiqamah dalam menjalankan ajaran agama baik dalam bentuk amaliyah syariah maupun

${ }^{9}$ Abd. Rahman an Nahlawi, 1992. Prinsip-Prinsip dan Metode Pendidikan Islam, diterjemahkan Dahlan \& Sulaiman, Bandung: Dipenegoro, h. 390

${ }^{10}$ Rasyid Ridha, tt. Tafsir al-Manar, Jilid II, Mesir: Maktabah al-Qahirah, h. 404 
dalam peraturan yang diciptakan oleh Kyai di Pondok. Dalam pendidikan ini tentu terdapat peraturan baik tertulis maupun tidak yang diketahui oleh seluruh warga pondok dan disitu terdapat pula hukuman atau sanksi bagi yang melanggar. Untuk menjadikan disiplin berjalan efektif, maka Kyai umumnya memberi wewenang kepada santri senior untuk mengontrol pelaksanaan disiplin ini dan karena itu segala masalah yang ditimbulkan oleh disiplin ini akan diselesaikan oleh Kyai sendiri. Disini kekuatan figure Kyai lagi-lagi merupakan faktor terpenting dalam pendidikan disiplin ini.

\section{Pendidikan Kemandirian}

Kemandirian adalah ciri penting yang melekat dalam sistim pendidikan pesantren. Dari aspek kelembagaan pesantren adalah lembaga swasta yang mandiri dan tidak bergantung kepada lembaga apapun. Kyai di pesantren adalah juga seorang figur yang mandiri secara ekonomi dan tidak menjadi pegawai siapapun. Santri yang belajar di dalam pondok adalah juga mandiri karena santri, dalam tradisinya, mengurus keperluan mereka sendiri, dalam masalah konsumsi dan akomodasi. Dalam pesantren model kelima para santri diberi hak untuk mengelola dapur, kantin, toko kelontong, foto copy dan aktifitas-aktifitas kesantrian lainnya. Artinya tanpa didampingi orangtua para santri dapat hidup berdikari bersama teman-teman mereka di pesantren.

Suasana pendidikan yang seperti tersebut diatas adalah gambaran tentang pengkajian Islam yang tidak melulu berisi aspek-aspek kognitif, tapi juga mencakup aspek-aspek lain yang lebih luas. Artinya di dalam sistim pendidikan pesantren, Islam tidak hanya dikaji tapi pada saat yang sama juga diamalkan. Inilah ciri khas sistim pendidikan pesantren. Sistim pendidikan yang menekankan pada kajian kitab-kitab turath mungkin banyak ditemui di Negaranegara Islam, namun pengkajian Islam yang diintegrasikan dengan pengamalannya dalam suatu lingkungan yang disebut pesantren hanya terdapat di nusantara. Inilah sistim pendidikan yang khas pesantren yang dapat dikembangkan dan disebar luaskan ke Negara-negara lain.

Apa yang menjadi kelebihan pesantren, sesungguhnya adalah sistimpendidikanyang diwarnai oleh jiwa serta nilai-nilai akhlaq. Sistim ini dipimpin oleh seorang kyai yang memiliki otoritas dan integritas keilmuan serta idealisme yang tinggi, berjiwa ikhlas, jujur, istiqamah, dan bermental pejuang. Kekuatan figure Kyai inilah sejatinya yang merupakan tiang dan kekuatan utama bangunan sistim pendidikan pesantren, sejak dulu hingga sekarang. Struktur keilmuan seperti ini mencerminkan totalitas sistim pendidikan yang terintegrasikan dengan sistim kehidupan dimana din tidak hanya dipahami secara kognitif tapi juga diamalkan secara afektif. Santri datang ke suatu pondok bukan hanya karena kepakaran Kyai dalam bidang ilmu tertentu tapi juga kharismanya dan integritas moralnya. Dalam bidang keilmuan telah menjadi tradisi jika suatu pesantren dipimpin oleh Kyai yang pakar hadith, maka santri peminat hadith berdatangan kepadanya. Demikian pula dalam bidang Fiqih, Tafsir, Nahwu Sorof dan lain-lain. Kyai Mahfuz Termas, misalnya pakar Fiqih dan Hadith, Kyai H.S. Hasyim Asy'ari di Jombang, pakar Hadith, Kyai Abu Amar di Jamsaren pakar tafsir, Arsyad alBanjari di Martapura pakar Fiqih dan falak, dan banyak lagi contoh lainnya. Tradisi ini adalah kelanjutan tradisi intelektual Islam dimasa lalu, dan kini bahkan ditiru di Barat, dimana mahasiswa mendaftar ke suatu fakultas karena disitu terdapat seorang Professor yang otoritatif dalam disiplin ilmu tertentu. 
Karena jiwa, alam pikiran dan idealisme Kyai sangat dominan maka interaksi Kyai santri secara gradual dan alami telah melahirkan suatu lingkungan kehidupan dengan tata nilai dan suasana kejiwaan yang mampu mengintegrasikan pendidikan dan kehidupan sehingga pesantren memiliki catur pusat pendidikan yaitu 1) Masjid, 2) masyarakat didalam dan luar pesantren, 3) asrama sebagai rumah tangga dan 4) pengajian sebagai sekolah.

\section{Studi Islam di Pesantren}

Kurikulum pondok atau pesantren pada umumnya sama dengan kurikulum pendidikan tradisional di dunia Islam sekarang ini, khususnya yang bermazhab Syafii dan aqidah Ash'ariyyah. Pada pondok pesantren salaf, kurikulum disusun ke dalam tiga tingkatan: Tingkatan Dasar (Ula) terdiri dari aqidah, Fiqh, Akhlaq, metode membaca al-Qur'an. Pada Tingkat Menengah (Wusta) terdiri dari aqidah, Fiqh, Akhlaq belajar, Nahw, Tajwid. Pada tingkatan Menengah Atas ('Ulya) meliputi: Aqidah, Fiqh, Akhlaq dan Tasawwuf, falsafah hukum Islam (Usul Fiqh), Tafsir, ilmu Hadith, Nahw, Mantiq (pada pondok tertentu sahaja). ${ }^{11}$

Di masa lalu pada pesantren Tebuireng kitab yang diajarkan meliputi sebelas bidang kajian: al-Qur'an, tafsir, hadits, ilmu hadits, bahasa Arab, tauhid/aqidah, akhlak, tasawuf dan mantiq. Namun, kitab-kitab kuning dalam bidang-bidang tersebut diajarkan berdasarkan pada tingkatan. Pada tingkat dasar kitab yang digunakan masih bersifat elementer dan relatif mudah dipahami. Misalnya, 'Aqîdah al-'Awwâm (tauhid), Safînah al-Najâh (fiqh), Washâya al-Abnâ' (akhlak) dan Hidâyah alshahibyân (tajwid). Pada

${ }^{11}$ Lihat http://www.let.uu.nl/ martin. vanbruinessen/personal/publications/kitab_ kuning.htm). tingkat menengah kitab yang digunakan, yaitu: Matan Taqrîb, Fath al-Qarîb dan Minhâj al-Qawîm (fiqh), Jawâhir al-Kalâmiyyah dan alDîn al-Islâmî (tauhid), Ta'lîm al-Muta'allim (akhlak), 'Imrithi dan Nahwu al-Wâdhih (nahwu), al-Amtsilah al-Tashrîfiyyah, Matan al-Binâ' dan Kaelani (sharaf) serta Tuhfah alAthfâl, Hidâyah al-Mustafid, Musyid al-Wildân dan Syifâ al-Rahmân (tajwid).

Pada tingkat atas kitab yang digunakan, yaitu: Jalâlayn (tafsir), Mukhtâr al-Hadîts, al-Arba'în Nawâwi, Bulûgh al-Marâm dan Jawâhir al-Bukhâri (hadits), Minhâj alMughîts (musthalah hadits), Tuhfah al-Murîd, Husûn al-Hamîdiyyah, 'Aqîdah Islâmiyyah dan Kifâyah al-'Awwâm (tauhid), Kifâyah al-Akhyâr dan Fath al-Mu'în (fiqh), Waraqat al-Sulâm (ushul fiqh), Alfiyyah Ibnu Mâlik, Mutammimah, 'Imrithi, Syabrawi dan al-'Ilal (nahwu dan sharaf) serta Minhâjj al-'Âbidîn dan Irsyâd al'Ibâd (tasawuf/akhlak). Pada pesantren ini kitab al-Munawwarah digunakan sebagai pelajaran mantîq (logika formal), yang berisi logika Aristoteles dan lainya. ${ }^{12}$

Adapun jumlah prosentase (percentage) dari semua jenis kitab-kitab di pondok tradisional (salaf) adalah sebagai berikut: fiqh) $20 \%$; ' aqidah, usul al-din $17 \%$; nahw, sarf, balagha $12 \%$; Hadith $8 \%$; Tasawwuf dan Tariqa $7 \%$; Akhlaq $6 \%$. Kumpulan du' a, wird, mujarrabat $5 \%$; dan bacaan tentang qisas alanbiya, mawlid, manaqib, etc.) $6 \% .^{13}$ Lihat table dibawah ini:

12 Mastuhu, 1994. Dinamika Sistem Pendidikan Pesantren: Suatu Kajian tentang Unsur dan Nilai Sistem Pendidikan Pesantren, Jakarta: INIS, h. 173.

13 Kajian Martin van Bruinsen menunjukkan bahwa kajian kitab Hadith hanya $8 \%$, tasawwuf $7 \%$, akhlak 6\%, doa wiridan mujarrabat $6 \%$. Martin van Bruinessen, "Kitab Kuning: Books in Arabic Script Used in the Pesantren Milieu", Bijdragen tot de Taal-, Land- en Volkenkunde 146 (1990), h. 226-269. 
Tabel: 1

Jenis Kitab-Kitab yang diajarkan Pesantren

Tradisional/Salafiyah

\begin{tabular}{|l|c|}
\hline Fiqh & $20 \%$ \\
\hline 'Aqidah, Usul al-din & $17 \%$ \\
\hline Nahw, Sarf, Balaghah & $12 \%$ \\
\hline Hadith & $8 \%$ \\
\hline Tasawwuf, Tariqah & $7 \%$ \\
\hline Akhlaq & $6 \%$ \\
\hline Du'a, wird, mujarrabat & $5 \%$ \\
\hline Qisas al-anbiya', mawlid, manaqib, etc.) & $6 \%$ \\
\hline
\end{tabular}

Jadi secara umum pengajaran di pondok pesantren didominasi oleh Figh, Aqidah dan Usuluddin, (49 \% dari kitab yang diajarkan dan dipelajari santri). Pengajian kitab-kitab fiqih yang mendominasi kajian di pesantren salafiyah itu hanya terbatas pada kitabkitab karya para ulama Syafi'iyah. Mulai dari kitab-kitab fiqh tingkat dasar, seperti "Safinatu-n-Naja", "Taqrib", "Kifayat-ulAkhyar", menengah ("Fathul Qarib", "Fathul Wahab", "Fath-ul-Mu'in", "I'anatut Thalibin", "Hasyiyah Bajuri", "Muhazzab"), hingga tingkat tinggi ("Nihayatul Muhtaj", "Hasyiyah Qalyubi wa Umairah", "Al-Muharrar", "Majmu Syarh Muhazzab"). Yang menjadi masalah apakah pesantren yang bertakhassus pada kajian kitab turath dapat menjadi referensi bagi kajian Islam di lembagalembaga pendidikan umat Islam dari tingkat menengah hingga perguruan tinggi? Lebih speisifik lagi apakah kajian fiqih tersebut dapat memberi menjawab tantangan yang dihadapi oleh umat dewasa ini? Apakah misalnya kajian Fiqih di pesantren mampu memberi kontribusi terhadap pengembangan ekonomi syariah yang sedang gencar-gencarnya dikembangkan di berbagai perguruan tinggi di dalam maupun di luar negeri. Pertanyaan serupa dapat diajukan untuk disiplin ilmu lain seperti tafsir, hadith, fiqih, filsafat, kalam dan lain-lain.

Namun, diantara pesantren ada yang telah mengembangkan tingkat perguruan tinggi dalam bentuk Sekolah Tinggi atau Institut, dan telah mengikuti standar ilmu pengetahuan yang tidak lagi terbatas pada kitab-kitab klasik yang dipelajari di pesantren dan merujuk kitab-kitab yang telah disusun oleh ulama kontemporer. Kajian Islam di tingkat ini sudah berbentuk fakultas seperti Usuluddin dengan program studi aqidah dan filsafat, perbandingan agama, tafsir al-Qur'an, hadith dan lainlain; Fakultas Syariah dengan program studi Perbandingan Mazhab, Muamalat, Hukum Ekonomi Syariah, dan lain sebagainya; Ilmu Tarbiyah dengan program studi Pendidikan Agama Islam, Pendidikan Bahasa Arab. Fakultas Dakwah, fakultas Adab (sastra Arab) dengan program studi Sastra Arab, Sejarah Peradaban Islam dan lain sebagainya.

Namun, karena masalah Sumber Daya Manusia perguruan tinggi pesantren ini pada umumnya tidak mengalami perkembangan yang menggembirakan. Kualitas pendidikan dan pengajaran, penelitian dan pengabdian masyarakat yang merupakan Tri Dharma Perguruan Tinggi tidak dapat bersaing dengan perguruan tinggi Islam negeri, apalagi dengan perguruan tinggi di Timur Tengah. Sekolah Tinggi dan Institut pesantren pada umumnya masih memerlukan binaan perguruan tinggi Islam negeri dalam hal ini dibawah Koordinator Perguruan Tinggi Swasta (Kopertais). ${ }^{14}$

Perkembangan lain dari perguruan tinggi pesantren adalah meningkatkan Sekolah-sekolah Tinggi atau Institut menjadi Universitas-universitas. Diantara yang dapat

14 Data yang dimiliki Litbang Depdiknas menunjukkan, dari 120.000 dosen tetap PTS dan PTN di Indonesia, masih ada 50,65 persen atau sekitar 60.000 di antaranya belum berpendidikan S2 atau baru S1. Menurut data lain, jumlah seluruh dosen di PTN sebanyak 240.000 orang, 50\% di antaranya belum memiliki kualifikasi pendidikan setara S2. Di antara jumlah tersebut, baru $15 \%$ dosen yang bergelar doktor 
disebutkan disini adalah Universitas Darul Ulum, Universitas Asy-Syafiiyyah Jakarta, Universitas Ath-Thahiriyyah Jakarta, Universitas Hasyim Asy'ari, Tebuireng, Universitas Mambaul Ulum, Jombang, Universitas Pesantren Darul Ulum, Jombang, Universitas Darussalam Gontor dan lain sebagainya. Dari sisi kualitas kelembagaan di tingkat nasional universitas-universitas pesantren ini harus bersaing keras tidak saja dengan universitas-universitas negeri tapi juga dengan universitas-universitas swasta milik Muslim ataupun non-Muslim. Ditingkat internasional universitas pesantren dituntut untuk berprestasi seperti universitas negeri, sementara kualitas universitas negeri di Indonesia di tingkat internasional masih jauh dari membanggakan. Dari 108 Perguruan Tinggi Negeri dan 3.199 Perguruan Tinggi Swasta hanya dua universitas (ITB dan UI) yang mendapat ranking internasional. Dari sisi keilmuan perguruan tinggi pesantren perlu mempertahankan karakteristik pesantren dan bahkan mengembangkan model pengkajian Islam yang mengintegrasikan ilmu dan akhlaq, yang dipimpin oleh seorang atau beberapa orang ulama yang otoritatif dalam bidangnya, yang menggunakan sistim pondok dan nilainilai kepesantrenan yang telah menjadi tradisi.

\section{Trend Studi Islam di dunia}

Terdapatbeberapa catatan tentang trend studi Islam di seluruh dunia. Disini gambaran studi Islam dapat dibagi menjadi dua yaitu di dunia Islam dan di dunia Barat. Di Negaranegara Islam studi Islam masih di dominasi oleh pembagian fakultas berdasarkan disiplin ilmu pengetahuan tradisional Islam seperti Usuluddin, Tarbiyah, Syariah, al-Qur'an, Tafsir, Hadith dan sebagainya. Perkembangan terakhir dalam fakultasfakultas tradisional di Negara-negara Islam seperti Jordan, Mesir, Qatar, Pakistan,
Malaysia, Saudi Arabia program studi ekonomi dan keuangan Islam telah lama berdiri dan telah menghasilkan pakar-pakar dibidang ini. Metodologi dan pendekatan yang berkembang dalam studi ekonomi Islam adalah integrasi dan Islamisasi. Bahkan sejak tahun 1990-an, studi ekonomi Islam telah dikembangkan di berbagai universitas di negara-negara Barat, seperti di Eropa, Amerika Serikat dan Australia. Di Inggris terdapat University of Durham, University of Portsmouth, Markfield Institute of Higher Education, University of Wales Lampeter, dan Loughborough University. Di Amerika Serikat, Harvard University, sangat aktif melakukan kajian ekonomi Islam. Di Australia, University of Wolongong juga melakukan hal yang sama.

Di Barat dapat dibagi menjadi studi Islam di Eropah dan di Amerika Serikat. Kajian para pakar menunjukkan bahwa studi Islam di AS pada mulanya berdasarkan pada tradisi kesarjanaan Orientalis dan teologi Kristen, yang menekankan secara kuat pada teks, namun hal ini terus berkembang dengan bertumpang tindih dengan Studi Kawasan Timur Tengah (Middle East area studies) dan juga beberapa disiplin ilmu humaniora dan ilmu sosial, khususnya studi agama-agama. ${ }^{15}$ Karena dikaitkan dengan disiplin ilmu humaniora maka studi Islam digunakan untuk mencari sumber-sumber sejarah Islam dalam kaitannya dengan hubungan antara masyarakat AS dan masyarakat Islam. Peristiwa 9/11 tidak saja mengakibatkan menjamurnya studi Islam,

${ }^{15}$ Charles Kurzman \& Carl W. Ernst, Islamic Studies in U.S. Universities" The University of North Carolina at Chapel Hill, September 30, 2009, Paper for Social Sciences Research Council workshop on "The Production of Knowledge on World Regions: The Middle East", hal. 1 ; Lihat juga SH.Nasr, Islamic Studies in America, dalam Sulayman S. Nyang, Mumtaz Ahmad, and Zahid H. Bukhari, The State of Islamic Studies in American Universities, The International Institute of Islamic Thought, 1431AH/2009CE, h 18. 
tapi juga memberi dorongan baru untuk memahami, menganalisas Islam, khususnya untuk menguji kemungkinan adanya hubungan antara ajaran Islam di satu sisi dan tindak kekerasan terrorisme. ${ }^{16}$

Maka dari sini berdirilah berbagai fakultas, program studi atau pusat studi Islam di AS. Di The University of Arkansas didirikan King Fahd Center for Middle East and Islamic Studies (2000), di Columbia International University didirikan Zwemer Center for Muslim Studies (2000), di the University of North Carolina at Chapel Hill's Carolina didirikan Center for the Study of the Middle East and Muslim Civilizations (2003); di the U.S. Naval Academy didirikan Center for Middle East and Islamic Studies (2005); The Lutheran School of Theology mendirikan Chicago's Center ofChristian-Muslim Engagement for Peace and Justice (2006); The Graduate Theological Union mendirikan Center for Islamic Studies (2007), Merrimack College mendirikan Center for Jewish-Christian-Muslim Relations (2008); The University of Southern California and the Hebrew Union College mendirikan Jewish Institute of Religion's Center for Muslim-Jewish Engagement (2008); Lehigh University mendirikan Center for Global Islamic Studies (2009).

Namun maraknya pendirian fakultas, program studi maupun pusat studi Islam diatas, seperti yang dinyatakan Charles Kurtzman, Sulayman dan Nasr, ditandai oleh perubahan dasar dan arah studi Islam dari pendekatan teologis para Orientalis kepada pendekatan disiplin ilmu sosial. Bahkan perlu dicatat bahwa fakultas, program studi maupun pusat studi ini tidak ada yang secara ekslusif fokus pada studi Islam, yang

16 Sulayman S. Nyang, Mumtaz Ahmad, and Zahid H. Bukhari, The State of Islamic Studies in American Universities, The International Institute of Islamic Thought, $1431 \mathrm{AH} / 2009 \mathrm{CE}$, Lihat Introduction ; lihat juga Charles Kurzman \& Carl W. Ernst, Islamic Studies in U.S. Universities, h.1 ada pada umumnya mencampur studi Islam dengan studi kawasan atau hubungan antar agama. Maka dari itu di Universitas Texas dan Washington studi Islam diletakkan di dalam kajian Timur Tengah, di Berkeley studi Islam digabungkan dalam Middle East center; di Michigan dan UCLA studi Islam bahkan digabungkan dalam International Centers. Di Columbia University, studi Islam di masukkan dalam The School of General Studies. Di dalam fakultas-fakultas yang tidak memiliki program studi Kajian Timur Tengah, atau pusat studi program studi Islam diletakkan pada program studi khusus, seperti Religious Studies di UNC-Charlotte.

Apayangmenjaditrend di AS nampaknya telah menjalar kepada studi Islam di Negaranegara Islam, khususnya di Asia Tenggara. Kamaruzzaman et al, menyimpulkan bahwa studi Islam pada mulanya di dominasi oleh penafsiran dan pemahaman terhadap kitab suci, pada beberapa tahun terakhir ini telah berkembang tren yang mengarah pada penggunaan pendekatan disipliner dalam memahami fenomena keagamaan pada masyarakat Islam. Artinya studi Islam didekati dengan berbagai disiplin ilmu sosial. Maka dari itu bidang studi Islam sekarang ini meliputi berbagai displin ilmu yang sangat luas termasuk anthropologi, sosiologi, ilmu politik, ekonomi dan beberapa bidang interdisipliner seperti studi gender dan studi kawasan. Para pengkaji Islam dalam disiplin ini juga merubah perhatian mereka kepada kajian Islam dan masyarakat Islam. Oleh sebab itu topik-topik yang menjadi kajian para pakar untuk memahami masyarakat Muslim menjadi bervariasi sehingga meliputi masalah demokrasi dan pluralisme politik, sekularisme, gender, hukum, HAM, etika, perkembangan ekonomi, lingkungan 
hidup, kutlur yang popular, konsumerisme, keuangan Islam, dan lain sebagainya. ${ }^{17}$

Trend ini bukan merupakan perkembangan studi Islam dari dalam umat Islam sendiri atau dari tradisi intelektual Islam sendiri. Perkembangan ini disebabkan oleh beberapa faktor diantaranya adalah Peristiwa 11 September 2001 dan deklarasi Negara-negara Barat untuk berperang melawan terror, sehingga studi Islam diarahkan kepada masyarakat Islam yang memiliki gejala-gejala adanya gerakan terror. Hal ini juga diantara penyebab para pengkaji Islam yang berasal dari luar tradisi keagamaan Islam ikut melakukan kajian terhadap Islam

dan umat Islam. Mereka itu memiliki sumber-sumber ilmu pengertahuan Islam yang cukup memadahi dan mampu menggunakan metodologi mutakhir dalam penelitian serta didukung oleh suasana kebebasan akademik.

Namun, meskipun mereka itu Muslim pemahaman dan penafsiran mereka terhadap Islam terpengaruh oleh status mereka yang tumbuh dan membesar diluar tradisi Islam atau diluar Negara Islam, oleh pengetahuan mereka tentang kitab suci masih tergolong kurang dan oleh kualitas keterikatan secara individual terhadap ajaran Islam juga dianggap minim. ${ }^{18}$

Trend studi Islam di Eropah, khususnya di Inggeris, tidak jauh beda dari studi

${ }^{17}$ Kamaruzzaman Bustamam-Ahmad \& Patrick Jory, (Editors) Islamic Studies And Islamic Education In Contemporary Southeast Asia, Yayasan Ilmuwan, Kuala Lumpur, 2011, lihat Introduction; lihat juga Fazlur Rahman, "Approaches to Islam in Religious Studies: Review Essay", dalamApproaches to Islam in Religious Studies, di edit oleh Richard C. Martin (Tucson: The University of Arizona Press, 1985); h. 11

${ }^{18} \mathrm{Ibid}, \mathrm{h}$. v. Atau Lebih detail tentang isu ini lihat Howard Federspiel, "Modernist Islam in Southeast Asia: A New Examination", The Muslim World Vol. 92 (2002).
Islam di Amerika. Sejarahnya, studi Islam dan masyarakat Islam sebagai suatu bidang akademik di UK berdasarkan pada orientalisme yang dalam hal ini merujuk kepada kajian kultur dan bahasa di dunia Islam, termasuk Timur Tengah. Perkembangan studi Islam berlangsung dan dipengaruhi oleh factor sejarah dimana umat Islam berada. Yang menonjol dari perkembangan itu adalah setelah Peristiwa 11 September 2001 dimana suasana dan pendekatan disipliner terus berkembang. Meskipun pengajaran studi Islam sebagiannya masih dalam lingkup khazanah Orientalism. Studi Islam yang berdasarkan pada tradisi Orientalisme dapat dilihat sebagai suatu disiplin tersendiri dengan metodologi, subyek-subyek utama dan teksteks kunci.

Namun studi Islam dan masyarakat Islam berlangsung pada tingkat multi-disiplin berfokus pada dunia Islam, khususnya Timur Tengah dengan penekanan pada kajian Bahasa Arab, Persia, Turkey; ditambah dengan kajian teks-teks Islam termasuk al-Qur'an dan Hadith. Pendekatan ini ditopang oleh pakar yang berasal dari sejumlah disiplin ilmu seperti Studi agamaagama, Sejarah, Bahasa dan Sastra, Politik, Anthropologi dan sosiologi serta bidangbidang studi interdisipliner dalam studi Timur Tengah dan Asia Selatan. Singkat kata, meskipun studi Islam di Inggeris khususnya, dan Eropah pada umumnya, melahirkan berbagai pendekatan dalam studi Islam, namun tradisi kajian Ketimuran serta cara pandang teologis terhadap Islam masih dianggap sangat penting. ${ }^{19}$

Dari trend studi Islam di Barat, baik di Amerika maupun di Eropah dapat

19 International Approaches to Islamic Studies in Higher Education, A report to HEFCE, Subject Centre for Languages, Linguistics and Area Studies Subject Centre for Philosophical and Religious Studies, June 2008, h. 11 
ditarik suatu kesimpulan bahwa trend mengkaji Islam dari berbagai disiplin ilmu sosial telah menjadi fenomena umum di Negara-negara itu. Hal ini disebabkan oleh beberapa faktor dan terutamanya adalah keragaman para pengkaji Islam dari luar Islam yang kurang penguasaan mereka terhadap khazanah Islam sehingga lebih mengutamakan pendekatan disiplin ilmu diluar Islam daripada Islam sendiri. Karena keadaan ini maka Seyyed Hossein Nasr mempertanyakan apakah model kajian ilmu sosial Barat itu cocok untuk dunia Islam? Apakah mungkin mengkaji masyarakat Islam berdasarkan pada teori Durkheim, atau mengkaji bagian dari dunia Islam dari disiplin antropologi berdasarkan pada teori Levi-Strauss? Jawaban Nasr tentu hal itu tidak mungkin, dan karena itu ia memberi saran bahwa langkah yang harus diambil dalam studi Islam adalah mengkaji bidang ini dalam framework agama dan bukan suatu disiplin ilmu. Seperti yang telah disebutkan bahwa pada mayoritas lembaga pendidikan di AS Islam dikaji sebagai sejarah, bahasa, kultur, sistim politik dan lain sebagainya, dan bukan sebagai agama.

Dari kritikan SH Nasr diatas perguruan tinggi Islam seperti ditantang agar menciptakan pendekatan sendiri yang tidak melulu didominasi oleh disiplin ilmuilmu sosial yang merupakan produk dari tradisi, kultur, kepercayaan, ideology Barat. setidaknya ilmu-ilmu sosial Barat tersebut disaring dan diadapsi sehingga tidak lagi bertertangan dengan nilai-nila sosial atau worldview Islam. ${ }^{20}$

\section{PENUTUP}

Model pendidikan di pesantren adalah khas Indonesia dan tidak terdapat di Negara-negara lain. Untuk itu ciri khas

${ }^{20}$ SH.Nasr, Islamic Studies in America, Ibid, h. 22 ini perlu dipertahankan baik pada tingkat menengah maupun di tingkat perguruan tinggi atau universitas. Model studi Islam di pesantren pada tingkat menengah telah merupakan tradisi yang kuat meskipun perlu peningkatan dan pengembangan sesuai dengan tuntutan zaman dan masyarakat. Untuk merespon tren studi Islam di kancah internasional, maka pesantren perlu meningkatkan kualitasnya sebagai lembaga tafaqquh fiddin. Tafaqquh tidak hanya terbatas pada pendidikan dan pengajaran ilmu kepada santri pada tingkat menengah, tapi juga kegiatan pengkajian dan pengembangan ilmu-ilmu keislaman setingkat perguruan tinggi atau universtias dengan tetap berpegang pada sistim dan tradisi khas pesantren. Materi tafaqquh perlu diperluas spektrumnya kepada keseluruhan pemikiran dan peradaban Islam yang diklasifikasikan menjadi ilmu fardu ayn dan ilmu fard kifayah atau ilmu naqliyah dan ilmu aqliyah. Tuntutuan masyarakat Islam terhadap studi Islam di pesantren begitu kompleks sehingga pesantren tidak dapat lagi mempertahankan disiplin keilmuannya hanya pada kitab-kitab tertentu yang sangat terbatas. Lebih-lebih jika kitab-kitab itu dikaitkan dengan standar keilmuan ditingkat universitas, banyak kitab yang masih perlu ditambahkan. Sebab pada kenyataannya ketika pesantren mendirikan universitas atau sekolah tinggi, disiplin ilmu yang selama ini dikaji di pesantren tidak seluruh dapat diakomodir dalam kurikulum pada program-progam studi. Maka sangat strategis jika pesantren dapat memprakarsai kajian ilmu-ilmu syariah yang diperkaya dengan ilmu-ilmu modern, dan ilmu-ilmu kauniyyah yang diwarnai oleh cara pandang Islam.

Arus globalisasi yang tidak lagi dapat dibendung mengharuskan umat Islam untuk berfikir global dan menginternasional. Artinya dunia pesantren perlu 
meningkatkan standar kualifikasi lembaga pendidikannya ketingkat internasional. Dimasa depan pesantren harus dapat terlibat dalam mobilitas mahasiswa Internasional, pertukaran mahasiswa, menghadiri konferensi internasional, joint research, jaminan mutu dan benchmarking secara internasional dan yang tidak kalah pentingnya adalah meningkatkan penggunaan Bahasa Arab dan Bahasa Inggris sebagai media komunikasi akademik. Dan terakhir, untuk memenuhi tuntutan masyarakat terhadap peran pesantren dimasa depan ketokohan Kyai perlu dioreintasikan kepada figur intelektual yang otoritatif dalam ilmu-ilmu keislaman. Kyai dimasa depan adalah Kyai yang mampu memberi pencerahan pemikiran kepada ummat atau Kyai yang memiliki gagasan besar dalam pengembangan pengkajian Islam serta menjadi rujukan diperguruan tinggi formal dan modern.

\section{DAFTAR PUSTAKA}

Ahmad, Kamaruzzaman Bustamam- \& Patrick Jory, (Editors) (2011): Islamic Studies And Islamic Education In Contemporary Southeast Asia, Yayasan Ilmuwan. Kuala Lumpur,

Arifin, Muhamad (1991): Kapita Selekta Pendidikan (Islam dan Umum). Jakarta, Bumi Aksara,

Al-Ghazali (1977): Ihya Ulumuddin, Jilid III. Beirut, Dar-al-Mishri

an Nahlawi, Abd. Rahman (1992): PrinsipPrinsip dan Metode Pendidikan Islam, diterjemahkan Dahlan \& Sulaiman. Bandung, Dipenegoro

Bruinessen, Martin Van (1990): "Kitab Kuning: Books in Arabic Script Used in the Pesantren Milieu", Bijdragen tot de Taal-, Land- en Volkenkunde 146

Dhoefier, Zamakhsyari (1984): Tradisi Pesantren, studi Tentang Pandangan Hidup Kyai. Jakarta, LP3ES

Hamid, Abu (1983): “Sistem Pendidikan Madrasah dan Pesantren di Sulawesi Selatan", dalam Taufik Abdullah (ed), Agama dan Perubahan Sosial. Jakarta, Rajawali Press

Ismail SM (ed), (2000): Pendidikan Islam, Demokrasi dan Masyarakat Madani. Yogyakarta, Pustaka Pelajar, Cet. ke-1

International Approaches to Islamic Studies in Higher Education, A report to HEFCE, Subject Centre for Languages, Linguistics and Area Studies Subject Centre for Philosophical and Religious Studies, June 2008,

Federspiel, Howard (2002): "Modernist Islam in Southeast Asia: A New Examination", The Muslim World Vol. 92 
Kurzman, Charles \& Carl W. Ernst, Islamic StudiesinU.S. Universities" The University of North Carolina at Chapel Hill, September 30, 2009, Paper for Social Sciences Research Council workshop on "The Production of Knowledge on World Regions: The Middle East",

Mastuhu (1994): Dinamika Sistem Pendidikan Pesantren: Suatu Kajian tentang Unsur dan Nilai Sistem Pendidikan Pesantren. Jakarta, INIS

Nasr, Sayyed Hosen (2009): Islamic Studies in America, dalam Sulayman S. Nyang, Mumtaz Ahmad, and Zahid H. Bukhari, The State of Islamic Studies in American Universities, The International Institute of Islamic Thought

Nyang, Sulayman S., Mumtaz Ahmad, and Zahid H. Bukhari, The State of Islamic Studies in American Universities, The International Institute of Islamic Thought.

Ridha, Rasyid (tt): Tafsir al-Manar Jilid II. Mesir, Maktabah al-Qahirah

Rahman, Fazlur (1985): “Approaches to Islam in Religious Studies: Review Essay”, dalam Approaches to Islam in Religious Studies, di edit oleh Richard C. Martin, Tucson: The University of Arizona Press,
Wirosukarto, Amir Hamzah et.al., (1966): KH. Imam Zarkasyi dari Gontor Merintis Pesantren Modern. Ponorogo, Gontor Press

Wahid, Abdurrahman (2001): Menggerakkan Tradisi, Esai-esai Pesantren. Yogyakarta, LKIS

Yunus, Mahmud (1990): Sejarah Pendidikan Islam di Indonesia. Jakarta, Hidakarya

http:// www.let.uu.nl/ martin. vanbruinessen/personal/publications/ kitab_kuning.htm).

Bakar, Osman (1997): Hirarki Ilmu Membangun Rangka Pikir Islamisasi Ilmu menurut AlFarabi, Al-Ghazali, Qutb al-Din Syiraz, Terj. Purwanto, Bandung, Mizan.

Al-Attas, Syed Muh. Nuquib, (1978): "Islam and Scelarism", Kualalumpur, ABIM.

Burhanudin, Jajat dan Dina Afrianty, eds. (2009): "Mencetak Muslim Modern : Peta Pendidikan Islam Indonesia”. Jakarta, Raja Grafindo Persada.

Zarkasyi, Abdullah Syukri (1999) : "Pondok Pesantren Sebagai Alternatifuntuk Program Studi Islam di Asia Tenggara" dalam studi Islam Asia Tenggara, ed. Zainuddin Fanarie dan M. Thoyibi, Surakarta, Muhammadiyah University Press.

Hodgson, Marshall G,S, (1974) : The Venture of Islam, Chicago, The University of Chicago Press. 